\title{
A Jar of Shaykhs' Teeth: Medicine, Politics, and the Fragments of History in Kuwait
}

\author{
Laura Frances Goffman \\ School of Middle Eastern \& North African Studies, University of Arizona, Tucson, AZ, USA \\ Corresponding author. Email: lauragoffman@arizona.edu
}

\begin{abstract}
This article examines 'Abd al-Ilah al-Qina i’s early 20th-century melding of local, imperial, and transoceanic health practices alongside his 21 st-century reemergence as a protonational Kuwaiti doctor. In the early 20 th century, geographically and ideologically expansive horizons of health care fostered the emergence of hybrid medical practices. Facilitated by his access to multiple medical spheres and his proximity to Kuwait's rulers, 'Abd al-Ilah was uniquely positioned to meet the demands of health-seeking consumers. In the 21st century, Kuwaitis' search for a national history that naturalizes claims to citizenship has resulted in 'Abd al-Ilah's new designation as Kuwait's first doctor. Both processes-the interplay between local cultures of health and emergent institutions and the imagining of medical history as a nativist teleology-demonstrate how health-seeking and history-writing efforts of a range of historical actors have placed medicine at the center of politics in Kuwait.
\end{abstract}

Keywords: history; Kuwait; medicine; politics

'Abd al-Ilah al-Qina'i was attentive to the social status of the clientele of his dawäkhāna, or pharmacy, in Kuwait's central suq, so much so that he saved the teeth he pulled from local shaykhs and notables to relieve their dental pain, labeling each tooth with the name of its donor. He treated patients from across the social spectrum, but only those among the "rulers and the prominent men" enjoyed the honor of having their discarded teeth added to his collection. ${ }^{1}$ Born in Kuwait, 'Abd al-Ilah had been trained as a medical assistant in the British-run charitable dispensary at the beginning of the 20th century. But when the British shuttered their facility during World War I, he responded by opening his own medical shop in the heart of Kuwait's suq. He continued to operate his dawākhāna until the early 1940s, closing soon after Kuwait's nascent Department of Health established its first government clinic in 1939. 'Abd al-Ilah's jar of teeth exemplifies his melding of medical care and political capital in early 20th-century Kuwait. Over the course of his career, 'Abd al-Ilah would fill an entire glass jar with carefully inscribed teeth to leave to his descendants.

For 21st-century audiences, the jar of teeth anchors 'Abd al-Ilah's legacy of health care. His assortment of ledgers and his medical tools, rediscovered decades after 'Abd al-Ilah closed his shop in the face of encroaching state control over medicine, have prompted a range of explanations for 'Abd al-Ilah's significance as a medical professional and a founding protocitizen of modern Kuwait. I was able to access 'Abd al-Ilah's records because his descendants donated his notebooks to the Center for Research and Studies on Kuwait. In 2005, the center published reproductions of the pages as a book. The book opens with an introduction by Khalid al-Jarallah, a scholar of Kuwaiti health history, and includes lists of medicines and patients' names, photographs of tools used in the dawäkhāna, and a glossary of medical terms. These

\footnotetext{
${ }^{1}$ Khalid al-Jarallah, Dawakhana: Dirasa Tawthiqiyya fi Tarikh al-Kuwayt al-Sihhi min Khilal Dafatir 'Abd al-Ilah al-Qina' $i$ (Kuwait: Markaz al-Buhuth wa-l-Dirasat al-Kuwaytiyya, 2005), 31. Throughout this article, I refer to 'Abd al-Ilah al-Qina'i by his first name, 'Abd al-Ilah, to distinguish him from other members of the sizable al-Qina'i family. In the Kuwaiti dialect, al-Qina'i is pronounced al-Jina' $i$.

${ }^{2}$ Ibid., 28.

( $)$ The Author(s), 2021. Published by Cambridge University Press. This is an Open Access article, distributed under the terms of the Creative Commons Attribution licence (http://creativecommons.org/licenses/by/4.0/), which permits unrestricted re-use, distribution, and reproduction in any medium, provided the original work is properly cited.
} 


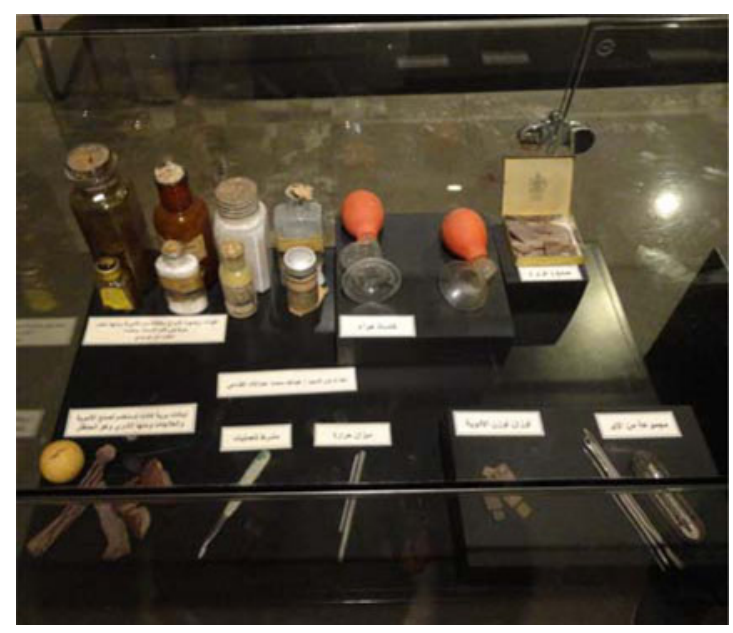

Figure 1. Medicines and tools displayed in the museum. Photograph by the author.

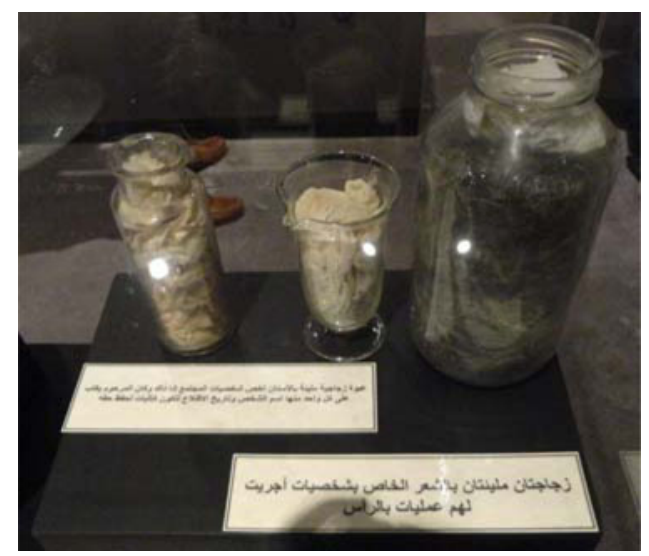

Figure 2. Jars of teeth and hair displayed in the museum. Photograph by the author.

remnants of 'Abd al-Ilah's professional life have prompted recent projects of historical reconstruction that situate his dawäkhāna in the narrative of Kuwaiti nation-building.

The most visible contemporary repository of 'Abd al-Ilah's legacy is a renovated museum filled with his meticulously labeled artifacts, including the jar of aging shaykhs' teeth (Fig. 1 and Fig. 2). Opened in 2011, the museum occupies the historic site of 'Abd al-Ilah's dawākhanna, at the heart of what is today Kuwait City's bustling Suq al-Mubarakiyya. The museum's location, as much as its contents, indicates how political and medical authority have converged in 'Abd al-Ilah's dawākhāna. The dawākhāna was under the kishk (kiosk) of Shaykh Mubarak al-Sabah (r. 1896-1915). ${ }^{3}$ It was here that Mubarak held "his daily majlis with the townspeople"; even after Mubarak's death, the kishk continued to operate as "essentially a courthouse" until 1938. ${ }^{4}$ As well as inhabiting the same double-story building, the lifespan of the kishk as a nexus of political authority closely paralleled the dawäkhāna's years of operation. 'Abd al-Ilah carried out his medical work literally under the gaze of the ruling shaykhs. Today, the museum's setting evokes 'Abd al-Ilah's intimacy with the nation's founding rulers. The top story holds political memorabilia and photographs of Kuwait's political elites; underneath, visitors encounter archaic jars of powdery substances and rusting medical tools.

\footnotetext{
${ }^{3}$ Ibid., 49.

${ }^{4}$ Farah al-Nakib, Kuwait Transformed: A History of Oil and Urban Life (Stanford, CA: Stanford University Press, 2016$), 31,42$.
} 
This article similarly juxtaposes past and present by examining 'Abd al-Ilah's proximity to political authority and his creative melding of local, imperial, and transoceanic health practices in the early 20th century alongside the more recent narratives driving his 21 st-century resurgence as a protonational doctor. In Kuwait at the turn of the 20th century, waves of epidemic disease and rising global sanitary concerns punctuated social and political life. 'Abd al-Ilah's medical training was the product of the efforts of imperial and local state actors to link public health to political authority, but 'Abd al-Ilah's career also demonstrates that medicine transcended coercive state responses to disease. Beyond state purview, his access to medical tools and pharmaceuticals depended on the myriad circuits and associations that connected Kuwait and Bombay. ${ }^{5}$ Finally, this medical hybridity did not result in a fixed set of practices that 'Abd al-Ilah thrust onto a passive community from the vantage point of his foreign-trained expertise. Rather, his dawäkhāna emerged as a feasible business because of a growing desire for institutionalized health services and imported pharmaceuticals among Kuwait's residents. 'Abd al-Ilah's entrepreneurial success resulted from his willingness and ability to meet the demands of these health-seeking consumers.

The life and afterlives of 'Abd al-Ilah demonstrate how national narratives of the present can obfuscate health practices of the past, yet we cannot separate our knowledge of 'Abd al-Ilah from the motivations behind the renewed interest in his life in Kuwait in recent years. The pathways through which 'Abd al-Ilah becomes visible to historians and contemporary Kuwaitis alike-the jar of shaykhs' teeth, the edited book containing his ledgers, and the museum-demonstrate how, in the 21 st century, new interpretations of medical equipment and family lore provide a field for Kuwaiti citizens to claim longstanding ties between native medical professionalism and the ruling elite. At the same time, selecting a single historical actor as a repository for the national past also entails an extensive erasure of the transregional connections and mixtures that facilitated the dawäkhāna's creation. In the early 20th century, the geographically, materially, and ideologically expansive horizons of health of local people fostered the emergence of hybrid medical practices. In the 21st century, Kuwaitis' search for a national history that naturalizes Arab and genealogical claims to citizenship has resulted in the invention of 'Abd al-Ilah as the first Kuwaiti doctor. Both processes-the interplay between local cultures of health and state-sanctioned institutions, and the imagining of medical history as a nativist teleology_demonstrate how the health-seeking and historywriting efforts of a range of historical actors have placed medicine at the center of politics and state formation in modern Kuwait.

\section{Health as Politics in Turn-of-the-Century Kuwait}

State-driven public health, a site of fierce competition, arrived in the Gulf at the intersection of global pandemic responses and local spheres of imperial influence. In Kuwait, the Ottomans and the British jostled for the right to quarantine potentially infectious travelers in response to pandemics of cholera and plague. In practice, the Gulf quarantine system was a haphazard jumble of buildings and regulations that encircled the region's littoral and (sometimes) forced (some) reluctant travelers to pause in time and space. $^{6}$ The Ottoman government failed to answer decisively Shaykh Mubarak's 1896 assassination of his brothers and subsequent rise to power. Even in the midst of this political drama, the Porte did manage to establish sanitary authority over Kuwait following the 1896 outbreak of plague in India. Indeed, the first state medical professionals in Kuwait were the Ottoman quarantine officer and his assistants, who were stationed in Kuwait from 1897-1901. ${ }^{7}$ But the sluggish Ottoman response to local upheaval allowed an opening for discussions that would result in the 1899 agreement between Britain and Shaykh Mubarak granting Kuwait protected status. ${ }^{8}$

\footnotetext{
${ }^{5}$ For a recent synopsis of the Indian Ocean turn in Gulf history, see Fahad Ahmad Bishara, "The Many Voyages of Fateh al-Khayr: Unfurling the Gulf in the Age of Oceanic History," International Journal of Middle East Studies 52, no. 3 (2020): 397-412.

${ }^{6}$ Laura Frances Goffman, "Medical Frontiers: Health, Empire, and Society in the Gulf and Arabian Peninsula, 1862-1959," (PhD diss., Georgetown University, 2019), ch. 1.

${ }^{7}$ Talal Sa'd al-Rumaydi, al-Kuwayt wa-l-Khalij al-'Arabi fi al-Salnama al-'Uthmaniyya (Kuwait: self-pub., 2009 ), 123.

${ }^{8}$ Frederick F. Anscombe, The Ottoman Gulf: The Creation of Kuwait, Saudi Arabia, and Qatar (New York: Columbia University Press, 1997), 91-112.
} 
Whereas quarantine stations suspended reluctant travelers by force, in the first decade of the 20th century the region's first dispensaries and hospitals attracted voluntary health-seeking patients. And, in another development that would have profound implications for Kuwaiti medicine, growing British influence in Kuwait created an opportunity for the American missionaries of the Arabian Mission to establish an outpost in the city. Mubarak initially resisted the missionary presence, but medicine, as the missionaries quickly realized, proved far more appealing to local constituents than did Bible sales. The American Arabian Mission opened a hospital in Bahrain in 1902, and as news of missionary medicine reached Kuwait residents started to demand similar health services. ${ }^{9}$ Largely in response to these regional trends of lingering Ottoman sanitary authority and encroaching missionary medical care, the British opened their charitable dispensary (later to be 'Abd al-Ilah's place of employment) and established sanitary inspections in Kuwait in $1904 .^{10}$

Quarantine stations and hospitals revolutionized governance in turn-of-the-century Kuwait by facilitating the authority of state agents over populations and individuals. But, beyond the purview of state officials and mission doctors, alternative networks of mobility and knowledge also fostered important transformations in Kuwaiti health. For example, responses to smallpox, a disease that killed between 25 and 50 percent of those infected and could leave survivors with skin scarring, blindness, and infertility, demonstrate evolving attitudes toward medical care. Health practitioners noted that those who recovered from this disease enjoyed a lifetime of protective immunity. ${ }^{11}$ A local man, Masa'ad bin 'Abd Allah al-'Azmi, introduced smallpox vaccination to this region as an enterprise that depended on personal interactions rather than institutionalized regulations.

Smallpox vaccination developed, in Kuwait as elsewhere, as a test of how effectively a diverse assortment of health-care campaigners could communicate the interconnected concepts of observation, prevention, and epidemic. Born in Kuwait around 1845, al-'Azmi fulfilled his lifelong dream of studying at al-Azhar when he made his way to Cairo in the 1870 s. $^{12}$ In Egypt, where Mehmed 'Ali Pasha (r. 1805-48) had ordered a countrywide smallpox vaccination program as early as 1819 , al-'Azmi befriended a doctor who taught him how to administer the prophylactic procedure. ${ }^{13}$ After completing his studies, al-'Azmi made his way home to the Gulf, stopping in India along the way to purchase vaccination equipment. He proceeded to spend the next several decades traversing the Arabian Peninsula, leaving a trail of vaccinated bodies in his wake. During the rule of Shaykh Muhammad al-Sabah (r. 1892-1896), al-'Azmi returned home to Kuwait. ${ }^{14}$ In contrast to the armed guards who policed the quarantine stations and to the foreign doctors who paired Bible readings with hospital treatment, al-'Azmi soothed the children he was vaccinating by chanting "musical, melodious poetry that he improvises" and that "distracts the child from the pain of the pricking and wounding." ${ }^{15}$ By transferring medical technologies from Egypt, via India, to Arabia, this wandering inoculator introduced smallpox vaccination to Kuwait without the oversight or intervention of European or American interlocuters, thus demonstrating to local people that preventive health was not necessarily associated with imperial or missionary hubris.

Whereas al-'Azmi established an important precedent of a local-born man offering smallpox vaccination, 'Abd al-Ilah differed from his predecessor in that he was the product of British medical training, and

\footnotetext{
${ }^{9}$ Khaled Albateni, “The Arabian Mission's Effect on Kuwaiti Society, 1910-1967” (PhD diss., Indiana University, 2014), 29-30, $50,62-63$.

${ }^{10}$ Al-Rumaydi, al-Kuwayt wa-l-Khalij al-'Arabi, 122-24.

${ }^{11}$ Sanjoy Bhattacharya, Mark Harrison, and Michael Worboys, Fractured States: Smallpox, Public Health and Vaccination Policy in British India, 1800-1947 (New Delhi: Orient Longman), 2.

${ }^{12}$ The exact dates vary between sources, which is not surprising given that his biography has been preserved through oral tradition. Al-Ghunayim reports 1874, and claims that he remained for seven years, until 1881 (Ya'qub Yusuf al-Ghunayim, Malamih min Tarikh al-Kuwait (Kuwait: self-pub., 1999), 111. See also 'Abd Allah Khalid al-Hatim, Min Huna Bada'at al-Kuwayt (Damascus: al-Matba'a al-'Umumiya, 1962), 147-48; Yusif al-Qina'i, Safahat min Tarikh al-Kuwayt, 4th ed. (Kuwait: Matba'at Hukumat al-Kuwayt, 1968), 45; Khalid al-Jarallah, Tarikh al-Khadamat al-Sihhiyya fi al-Kuwayt (Kuwait: Markaz al-Buhuth wa-l-Dirasat al-Kuwaytiyya, 1996), 160; Muhammad bin Ibrahim al-Shaybani, al-Amrad al-Fattaka $f i$ Tarikh al-Kuwayt: al-Ta'un, al-Judariyy, al-Influwanza (Kuwait: Markaz al-Makhtutat wa-1-Turath wa-1-Watha'iq, 2017), 74-75.

${ }^{13}$ Khaled Fahmy, "Women, Medicine, and Power in Nineteenth-Century Egypt," in Remaking Women: Feminism and Modernity in the Middle East, ed. Lila Abu-Lughod (Princeton, NJ: Princeton University Press, 1998), 42.

${ }^{14}$ Al-Hatim, Min Huna Bada'at al-Kuwayt, 148.

${ }^{15}$ Al-Ghunayim, Malamih min Tarikh al-Kuwait, 113.
} 
thus operated at the intersection of local and Western health practices. Indeed, the contest among Mubarak, the Ottomans, the British, and the missionaries over sanitary and medical authority had formed the backdrop to his early life. Born in Kuwait in 1890, 'Abd al-Ilah was the eldest son of the Mulla 'Abd Allah bin Muhammad (c. 1860/1865-1926). From 'Abd al-Ilah's childhood, his father had worked to position his son for success across multiple spheres. Mulla 'Abd Allah was well versed in the religious sciences, Arabic, calligraphy, and literature, and he oversaw the education of his sons. When 'Abd al-Ilah received his education right around the turn of the century, traditional kuttāb, or Qur'anic schools, "taught basic literacy, rudimentary arithmetic, and most importantly recitation of the Qur'an." ${ }^{\prime 6}$ The father, Mulla 'Abd Allah, briefly worked in Mubarak's customs house; then, in 1904, thanks to his education and his knowledge of English, he became a scribe for the British Political Agency. ${ }^{17}$ In 1909, it was Mulla 'Abd Allah who secured 'Abd al-Ilah's position as dispensary medical assistant. ${ }^{18}$

As 'Abd al-Ilah started his medical work in 1909, Kuwait was in the throes of a particularly deadly smallpox epidemic; in the same year, an outbreak of plague in Bahrain prompted Mubarak to order travelers to quarantine in their boats. As 'Abd al-Ilah first learned to treat patients, dress wounds, and administer vaccinations, the dispensary received over 5,000 patients over the course of the year. ${ }^{19}$ The dispensary, open from morning to 1 p.m. daily except on Fridays, was located in the agency house along the coast of Kuwait. ${ }^{20}$ Following the tenures of a series of Indian doctors, Assistant Surgeon C. C. Kelly took over medical duties in Kuwait on 18 May 1912, accompanied by his wife. The switch to Anglo-Indian supervision over the dispensary reflected the growing political importance of medicine in Kuwait and the explicit racialization of British representation in the Gulf after Lord Curzon, the Viceroy of India, declared the importance of "white British boots on the ground" at the beginning of the 20th century. ${ }^{21}$

By the 1910s intense competition between American Protestants and Kuwaiti Islamic modernists also resulted in the first indigenous project to institutionalize medicine. The missionaries had finally overcome the shaykh's initial opposition, opening a dispensary in 1910, a school in 1912, and a hospital in $1914 .^{22}$ The Kuwaiti merchant class enjoyed close ties to cities like Bombay and Basra and also "espoused Islamic modernist ideology" during this period. ${ }^{23}$ Enthusiastic readers of Rashid Rida's al-Manar (The Lighthouse), Kuwait's modernists were consummate reformers who "would lovingly nurture their community with spiritual rather than materialistic values, even when they needed money to realize their aims." ${ }^{24}$ In 1911, a group of Kuwaiti merchants and educated men joined together to start a local school (which would welcome students starting in 1912) intended to thwart missionary influence by offering history, geography, arithmetic, English, and Arabic. ${ }^{25}$ In 1913, following Rida's rousing visit to Kuwait, a group of reformist merchants formed al-Jam iyya al-Khayriyya al-'Arabiyya (the Arab Charitable Association). ${ }^{26}$ They recruited a Muslim doctor from Ottoman Basra to staff their new dispensary, which provided free health services to the poor. ${ }^{27}$ This project was short-lived; the doctor resigned

\footnotetext{
${ }^{16}$ Talal Al-Rashoud, "Modern Education and Arab Nationalism in Kuwait, 1911-1961" (PhD diss., SOAS, 2016$), 67$.

${ }^{17}$ Al-Jarallah, Dawakhana, 23.

${ }^{18}$ Ibid., 24.

${ }^{19}$ India Office Records (hereafter IOR), R/15/1/710, “Administration Reports 1905-1910,” 1909, 77.

${ }^{20}$ Al-Jarallah, Dawakhana, 24; IOR, R/15/6/504, “Administration Report on the Persian Gulf Political Residency and Maskat Political Agency for 1904-1905: Residency and Maskat Political Agency for the Year 1904-1905,” 159.

${ }^{21}$ Omar Al-Shehabi, "Political Movements in Bahrain Across the Long Twentieth Century (1900-2015)," in The Oxford Handbook of Contemporary Middle Eastern and North African History, ed. Amal Ghazal and Jens Hanssen (Oxford, UK: Oxford University Press, 2017), 2, https://doi.org/10.1093/oxfordhb/9780199672530.013.27.

${ }^{22}$ Arthur K. Bennet, "The Opening of Kuweit," Neglected Arabia no. 92 (1915), 7-8; Edwin E. Calverley, "Evangelistic Activities at Kuweit," Neglected Arabia no. 92 (1915), 8. My thanks to the reviewer who provided this citation.

${ }^{23}$ Al-Rashoud, "Modern Education and Arab Nationalism in Kuwait," 45.

${ }^{24}$ Leor Halevi, Modern Things on Trial: Islam's Global and Material Reformation in the Age of Rida, 1865-1935 (New York: Columbia University Press, 2019), 99.

${ }^{25}$ Suliman Al-Atiqi, “The Origins of Kuwaiti Nationalism: Rashid Rida's Influence on Kuwaiti National Identity,” Arab Studies Journal 23, no. 1 (2015): 81.

${ }^{26}$ Ibid., 93.

${ }^{27}$ Albateni, "The Arabian Mission's Effect on Kuwaiti Society,” 99; IOR, R/15/1/711, “Administration Report of the Persian Gulf Political Residency for the Years 1911-1914,” 1913, 127.
} 
the same year, forcing the dispensary to close. On the eve of World War I, the British dispensary and the mission hospital remained the only options for institutionalized medicine in Kuwait.

Within Kuwait's community of Islamic reformers, the brothers Yusuf bin 'Isa al-Qina'i (1876-1973) and Husayn bin 'Isa al-Qina'i (1878-1957) probably influenced how 'Abd al-Ilah experienced the currents of political and social life. Although the brothers were part of the same extended al-Qina'i family, they came from the bin Sirri al-Qina'i branch, whereas 'Abd al-Ilah was descended from al-'Abd al-Ilah al-Qina ${ }^{i} .{ }^{28}$ Yusuf, a religious scholar who had studied in al-Hasa, Basra, and Mecca, was one of the leading proponents of Islamic modernism in Kuwait. ${ }^{29}$ His brother Husayn journeyed to Bombay in 1914. One account suggests that Shaykh Mubarak asked Yusuf to appoint his brother Husayn to work in Kuwaiti customs on account of his skills in reading and writing, but Yusuf "didn't desire that." 30 Yusuf recounted in a 1966 television interview that after he rebuffed Mubarak's initial request to employ Husayn, Mubarak returned yet again to seek Husayn's participation in "one of the battles." ${ }^{1}$ Yusuf sought the intervention of Mubarak's son, Salim, and directed Husayn to emigrate to India. It made sense for Yusuf to guide his brother Husayn toward Bombay as the city was home to a significant community of Arabs from the Gulf. Bombay, easily accessible by a short steamship or sailboat journey, was a pearl emporium as well as the main destination of Gulf Arabs for medical treatment throughout the interwar period. ${ }^{32}$ In India, Husayn initially worked as an accountant for the prominent al-Ibrahim merchant family, where 'Abd al-Ilah would have found him when he arrived in Bombay in 1919.

'Abd al-Ilah's extended family, in short, enjoyed significant political and economic prestige, and they used these advantages to negotiate with-and even on occasion to contest-Kuwait's rulers. Surely it is no coincidence that Yusuf found himself opposing Mubarak's military exploits and avoiding family associations with the ruler at the start of World War I, when a group of pro-Ottoman Kuwaiti merchants protested Mubarak's support for the British. Mubarak's allegiance to the Ottomans formally continued until the outbreak of World War I, when he decisively sided with Britain. ${ }^{33}$ After his death in 1915, Mubarak's sons and successors, Jabir (r. 1915-17) and Salim (r. 1917-21), continued these pro-British policies, albeit under significant pressure from the political agency. Many of Kuwait's merchants opposed the heightened British imperial wartime presence. Disrupted communications with India hampered trade and led to shortages. Of particular concern to the British was the fact that Kuwaiti merchants were smuggling goods to Ottoman-controlled areas. The British administration forced Salim to accept a blockade of Kuwait Town in 1918 by threatening to divert steamships-and thus customs fees-from Kuwait to Basra. $^{34}$

'Abd al-Ilah continued his work in the British dispensary over the course of these wartime disputes. Wartime medical care was challenging for the dispensary staff; as the political agent wrote, "there being no hospitals or ambulance in Koweit, Assistant Surgeon Kelly has had personally to nurse, as well as prescribe for the patients." ${ }^{35}$ Typically, the political agent did not acknowledge local employees in his communications, although 'Abd al-Ilah would have been working alongside Kelly over the course of his duties in the charitable dispensary, quarantine inspections, and military details. ${ }^{36}$ On 2 September 1918 , the

\footnotetext{
28“Al-Qina iat," Alqenaei Net, accessed 16 June 2020, http://www.alqenaei.net. I am grateful to Shaikhah Abdullah Alqenai for sharing this family tree. The al-Qina $i$ trace their origins to Najd and have extended branches around the region in present-day Saudi Arabia, Bahrain, and Iraq, as well as Kuwait. See 'Abd Allah al-Madani, "al-Jina iat min Shaqra' ila al-Kuwayt ... ila Najah Tijari fi-l-Hind,” Okaz, 3 March 2019, https://www.okaz.com.sa/culture/na/1709759.

${ }^{29}$ Al-Rashoud, "Modern Education and Arab Nationalism in Kuwait," 56.

${ }^{30}$ Hussah al-Harbi, Tarikh al-'Alaqat al-Kuwaytiyya al-Hindiyya (Kuwait: self-pub., 2017), 385.

${ }^{31}$ Ibid., 386; 'Abd Allah al-Madani, “al-Jina'at al-Kuwaytiyyun wa-Hikayathum fi-l-Hind,” al-Bayan, 3 March 2019, https:// www.albayan.ae/five-senses/mirrors/2019-03-03-1.3502424.

${ }^{32}$ Muhammad Morsy Abdullah, The United Arab Emirates: A Modern History (London: Croom Helm, 1978), 107.

${ }^{33}$ Frederick F. Anscombe, The Ottoman Gulf, 132-40.

${ }^{34}$ John Slight, "Global War and Its Impact on the Gulf States of Kuwait and Bahrain, 1914-1918," War \& Society 37, no. 1 (2018): 29-30.

${ }^{35}$ IOR, R/15/5/13, Political Agent Kuwait to Chief Political Officer, Basrah, 27 November 1916.

${ }^{36}$ In medicine, as in other fields, the British tendency was to remain silent with regard to local contributions to the production of knowledge. For a discussion of this dynamic in the Gulf, see Nelida Fuccaro, "Knowledge at the Service of the British Empire: The Gazetteer of the Persian Gulf, Oman, and Central Arabia," in Borders and the Changing Boundaries of Knowledge, ed. Inga Brandell, Marie Carlson, and Önver A. Çetrez (Istanbul: Swedish Research Institute, 2015), 17-34.
} 
political agent received a telegram from Baghdad that abruptly ended Kelly's tenure in Kuwait, stating, "Kelly is posted to India and you should arrange for his return. Successor cannot be spared for Kuwait." ${ }^{\text {" }}$ With this terse command, Kuwait's British charitable dispensary closed, remaining out of operation until 23 May $1921 .^{38}$

\section{Medical Praxis Under the Shaykhs}

Not only was 'Abd al-Ilah left unemployed when the British dispensary shut its doors in September 1918, but the community also lost a major medical institution on the heels of the "unprecedentedly severe epidemic of small-pox" of 1917, which claimed several thousand lives. ${ }^{39}$ Moreover, in late October, just weeks after Kelly's departure, Kuwait was struck by the influenza pandemic, which killed more people globally than the First World War. "Hardly a house escaped," and the British Political Agency estimated as many as 4,000 deaths. ${ }^{41}$ In the wake of these cascading epidemic calamities, in 1919 'Abd al-Ilah set off for Bombay to purchase medical supplies. His Bombay-based relatives offered 'Abd al-Ilah access to tools, pharmaceuticals, and sanitary supplies. Upon his return to Kuwait, he opened a small shop under the shaykh's kishk in the central market. The kishk-and 'Abd al-Ilah's shop-were close to a wall where Kuwaiti authorities posted official announcements. 'Abd al-Ilah would turn to this wall to advertise his medical services and to promote smallpox vaccination. ${ }^{42}$ This new central location under the shaykh's kishk embedded the dawäkhāna in political life and provided strong evidence to the local community that Kuwait's rulers sanctioned 'Abd al-Ilah's medical work.

The interweaving of imperial medicine, local medical knowledge, communal experiences of epidemic disease, and British Indian pharmaceuticals characterized 'Abd al-Ilah's medical practice. When he set off to purchase supplies in 1919, boundaries between the "bazaar" and Western pharmaceutical companies were permeable in Bombay's competitive pharmaceutical marketplace. Categories of Western, Ayurvedic, allopathic, and Unani medicines, as Nandini Bhattacharya argues, "hardly represented the totality of the drug market and were reflective, often, of marketing strategies." 43 Demands for drugs of various prices also resulted in a proliferation of products of fluctuating concentrations. ${ }^{44}$ We should expect, then, that 'Abd al-Ilah's purchases in Bombay represented a mix of European, Anglo-Indian, and local products. Many of his patients, moreover, would have already been familiar with various brand names and active ingredients due to the longstanding movement of people and medicines between Kuwait and India.

'Abd al-Ilah's records confirm patterns of flexible medicating and, as al-Jarallah writes, "It is possible to divide the pharmaceuticals that he imported into two types: first, compound and manufactured drugs of Indian and English origins; and the second were medicines derived from herbs that were considered to have medicinal properties." ${ }^{45}$ One list of sales includes tooth medicine, cough medicine, iodine, and peppermint oil. ${ }^{46}$ Another consists of headache medicine, yellow fish oil, fish oil in white milk, hair arsenic,

\footnotetext{
${ }^{37}$ IOR, R/15/5/13, Political Agent Kuwait to Kelly, 2 September 1918.

${ }^{38}$ IOR, R/15/1/713, “Administration Reports 1920-1924,” 1921, 68.

${ }^{39}$ IOR, R/15/1/712, “Administration Report of the Persian Gulf Political Residency for the Years 1915-1919," $1917,51$.

${ }^{40}$ Pandemic mortality totals remain disputed, but were estimated at 50 million deaths, with as many as 14 million occurring in British India. See Olivia Reyes, Elizabeth C. Lee, Pratha Sah, Cécile Viboud, Siddharth Chandra, and Shweta Bansal, "Spatiotemporal Patterns and Diffusion of the 1918 Influenza Pandemic in British India," American Journal of Epidemiology 187, no.12 (2018): 2550-60, https://doi.org/10.1093/aje/kwy209.

${ }^{41}$ IOR, R/15/1/712, “Administration Report of the Persian Gulf Political Residency for the Years 1915-1919," 1918, 67. It is difficult to reach an accurate population estimate of Kuwait at the beginning of the 20th century. One British report stated that in 1901 Mubarak estimated a total of about 89,000 people within ten miles of Kuwait; IOR, L/PS/20/153, H. H. Dowding, "Koweit: A Report Compiled in the Intelligence Branch, Quarter Master General's Department" (Simla, India, 1903), 18. In 1915, the American missionaries estimated that the population of Kuwait Town was "as high as 50,000"; Gerrit J. Pennings, "Kuweit, The 'Little Walled Town," Neglected Arabia no. 92 (1915): 4.

${ }^{42}$ Al-Jarallah, Dawakhana, 39.

${ }^{43}$ Nandini Bhattacharya, "Between the Bazaar and the Bench: Making of the Drugs Trade in Colonial India, ca. 1900-1930," Bulletin of the History of Medicine 90, no. 1 (2016): 66.

${ }^{44}$ Ibid., 82-83.

${ }^{45}$ Al-Jarallah, Dawakhana, 60.

${ }^{46}$ Ibid., 57.
} 
peppermint oil, and almond oil. ${ }^{47}$ An interesting product that features in his sales records is the castor oil plant. ${ }^{48}$ This plant had circulated in the Indian Ocean world's pharmacopoeia since ancient times, and beginning in the 18th century Britain exported bulk drugs from colonized spaces for processing and resale. ${ }^{49}$ Something like castor oil might have had pre-imperial uses in Kuwait and then have reemerged as a "modern" treatment, or "Abd al-Ilah might have sold it as an herbal remedy in its premodern form alongside processed versions. According to his grandson, 'Abd al-Ilah prescribed local ingredients like sulfur coal and lamb lard alongside bottles of imported medicine. ${ }^{50}$ Adding to the complexity of his medical practice, 'Abd al-Ilah also drew from the healing techniques of al-tibb al-sha' $b \bar{\imath}$ (folk medicine) and al-țibb al-Islāmì (Islamic medicine) by performing circumcisions, cupping (al-hijāma), and cautery (al-kayy) "every day." 51

'Abd al-Ilah had been involved in smallpox vaccination in his years at the agency dispensary, and his new central location allowed him to promote this procedure in the heart of Kuwait's commercial district. 'Abd al-Ilah "proceeded to bring the smallpox vaccines from India, circulated advertisements, and provided vaccination services to those who were desirous among the people." 52 He turned to the market's public wall to advertise vaccination. Despite vaccination's already substantial history in Kuwait, in the 1920s the imported vaccine unfortunately all too often proved ineffective. ${ }^{53}$ A 1921 British report juxtaposed vaccination's wide acceptance with its technological failure: "The people have faith in vaccination, but the results have not proved satisfactory, as, owing to the distance, lymph received from India is inert." ${ }^{" 54}$ Despite this product's disappointing results, the fact that al-'Azmi had already introduced smallpox vaccination may have rendered it all the more palatable to 'Abd al-Ilah's patients, paving the way for him to convince Kuwaitis to visit his dawäkhāna for vaccination in the 1920s and 1930s.

Did 'Abd al-Ilah envision vaccination as a form of individualized care or as a means of protecting Kuwait's community as an interconnected collective? How did communal histories of disease shape his public messaging? To what extent did 'Abd al-Ilah depend on his proximity to political authority to legitimize this public health measure? In the public space of the market wall, 'Abd al-Ilah communicated the benefits of the smallpox vaccine by reminding potential patients of past hardships and spelling out how this preventive measure might forestall future epidemic tragedies. 'Abd al-Ilah posted the following advertisement:

\section{Announcement}

For 'Abd al-Ilah bin 'Abd Allah's shop

Under the kishk of the Shaykh, he will open his shop on the first day of Jamada al-Awwal

$\mathrm{He}$ is ready to provide vaccination that is not harmful to children

The destruction brought by smallpox last year prompted us to prepare two hundred; hopefully God makes it enough to prevent mistakes.

And we reduced the cost to two rupees.

So the wise one would rush with his two rupees and the ignorant one would delay. ${ }^{55}$

\footnotetext{
${ }^{47}$ Ibid., 153.

${ }^{48}$ Ibid., 93.

${ }^{49}$ Bhattacharya, "Between the Bazaar and the Bench," 68.

${ }^{50}$ Interview, Abdullah Mohammad Alabdullellah Alqenaei, Kuwait, 14 March 2019.

${ }^{51}$ Ibid.

${ }^{52}$ Al-Jarallah, Dawakhana, 27.

${ }^{53}$ By World War I, locally produced calf lymph preserved with lanolin or glycerin had overtaken arm-to-arm vaccination in British India. See David Arnold, Colonizing the Body: State Medicine and Epidemic Disease in Nineteenth-Century India (Berkeley, CA: University of California Press, 1993), 141.

${ }^{54}$ IOR, R/15/1/713, “Administration Reports 1920-1924," 1921, 69.

${ }^{55}$ Al-Jarallah, Dawakhana, 49. Although the poster unfortunately is undated, by the 1930 s the municipality routinely posted handwritten announcements promoting sanitation and vaccination to the walls of Kuwait's markets. See Khalid al-Jarallah, Sihhat al-Kuwayt: Qira'a fi Watha'iq Kuwaytiyya wa Ajnabiyya (Kuwait: Markaz al-Buhuth wa-l-Dirasat al-Kuwaytiyya, 2019), 183. It is possible that 'Abd al-Ilah posted this advertisement in the wake of the devastating smallpox epidemic of 1932, which according to mission doctor C. Stanley G. Mylrea claimed at least 3,000 lives; "Kuwait Before Oil: Memoirs of Dr. C. Stanley G. Mylrea, Pioneer Medical Missionary of the Arabian Mission Reformed Church in America" (Center for Research and Studies on Kuwait, unpublished manuscript, written between 1945 and 1951), 27.
} 
Further enforcing the significance of al-'Azmi's legacy, the absence of any reference to the British Political Agency or the mission hospital underscores the probability that Kuwaitis did not associate vaccination exclusively with imperial or missionary medicine. By locating the dawākhāna —and by extension, smallpox vaccination-in proximity to the shaykh's kishk, this announcement draws a clear line between smallpox vaccination and the ruler's endorsement of this public health measure. 'Abd al-Ilah's grandson told me that people's willingness to accept his vaccination services was a direct result of an epidemic that had left the community traumatized. He promoted this service by appealing to people's understanding of the danger of smallpox to children and a distinction between "wise" and "ignorant" reactions to recent experiences of disease.

As his dawäkhāna was a business and the source of his livelihood, 'Abd al-Ilah charged a modest fee for vaccination. Embedded in the local community, he sought to reconcile his "liminal position between profit and healing" so that he could earn an income by treating patients and selling medicine. ${ }^{56}$ The British charitable dispensary, the American Mission dispensary, and the Arab charitable dispensary had established a precedent of offering medical care without charge to those who could not afford their services. 'Abd al-Ilah also offered free treatment to those who could not pay, telling them they could compensate him whenever they had the means to do so. ${ }^{57}$ Another account states that he treated

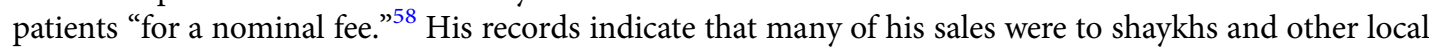
elites. Moreover, as was common for Gulf merchants who at this time ran their shops on credit, patients might accrue long tabs over time that included treatments for various members of their extended households.

Notes from his patients reveal their practices of self-diagnosis, offering clues as to how patients understood the relationship between their health and the remedies 'Abd al-Ilah dispensed. In 1924, 'Abd al-Ilah received a note from Khalid Yusuf al-Mutawwa' complaining of severe illness. ${ }^{59}$ He wrote, "I won't conceal from you that for three days now I've had a fever and excessive headache," and continued, "Provide me with medicine for drinking, enough to use for one time only, and give me the good stuff (al-tayyib), even it means a higher price, and write instructions for me on how to take the medicine." In another note 'Abd al-Ilah received the same year, Shaykh 'Ali al-Sabah requested that 'Abd al-Ilah "give our servant four bottles of syrup." 60 These letters were carried to 'Abd al-Ilah by servants or messengers of his patients, who identified their own symptoms and then wrote to him for medicines. 'Abd al-Ilah measured out the requested medication and noted into whose hands he had placed the treatment on the bottom of the letters.

Did 'Abd al-Ilah tend to sick women, as well as men? The British dispensary where 'Abd al-Ilah started his career treated women patients. There is evidence in local oral traditions that women healers treated men, although it is unclear to what extent men also treated women. For example, according to Muhammad bin Ibrahim al-Shaybani, 'Abd Allah Hanif recalled being cured by a healer named Umm Salman, stating, "She was a capable doctor who treated me in a way I'll never forget for the rest of my life. She used a hot nail . . . and thank God I healed. I became well, and I had seventy burn marks in my body, my illness had caused me pain all over my body because of carrying water from far away." ${ }^{1}$ Hanif does not indicate that receiving medical treatment from a woman was exceptional, despite the intimacy implied by placing hot nails on his body. He simply mentions her name and praises her skills and their beneficial impact on his health. Even though the 234 names that appear in 'Abd al-Ilah's records are all those of men, the lack of named women patients does not preclude the possibility that he also sold medicines to women. ${ }^{62}$ It is likely that 'Abd al-Ilah recorded the names of people with whom he had ongoing accounts rather than those of patients he was treating on a one-time basis. Even some of the

\footnotetext{
${ }^{56}$ Barbara Di Gennaro Splendore, "Craft, Money and Mercy: An Apothecary's Self-Portrait in Sixteenth-Century Bologna," Annals of Science 74, no. 2 (2017): 92.

${ }^{57}$ Interview, Abdullah Mohammad Alabdullellah Alqenaei, Kuwait, 14 March 2019.

${ }^{58}$ Sa ud al-Dayhani, “Abd al-Ilah al-Qina'i ... Awwal man Ansha' 'Iyada Tibbiyya 'ala al-Namat al-Hadith,” al-Ra'y, 10 June 2014, https://alraimedia.com/Home/Details?id=3f92657c-17bf-4507-a62d-6f629e202855.

${ }^{59}$ Al-Jarallah, Dawakhana, 50.

${ }^{60}$ Ibid., 50.

${ }^{61}$ A-Shaybani, al-Amrad al-Fattaka fi Tarikh al-Kuwayt, 27.

${ }^{62}$ Al-Jarallah, Dawakhana, 220.
} 
men he treated are listed in terms of their relationships to male heads of family. Given the patterns of self-diagnosis described above, there is a good chance that women would have assessed their own symptoms and then requested that servants or male relatives purchase medicines from 'Abd al-Ilah on their behalf.

At the crossroads of local networks and intellectual trends, British imperial medicine, an emerging Kuwaiti state, and changing conceptions of epidemic disease, 'Abd al-Ilah's dawākhāna was a quintessentially hybrid medical practice. Over the course of integrating his medical services into market life, 'Abd al-Ilah identified his shop by its location under the shaykh's kishk and took advantage of its proximity to a wall used for official announcements. Eliding the contributions of figures like al-'Azmi, British officials and the American missionaries claimed credit for introducing public health to Gulf populations at the beginning of the 20th century. 'Abd al-Ilah and his patients drew from this foreign milieu, but their health-seeking interactions depended just as much on the repositories of trust fostered in their interpersonal relationships and on their own evolving interpretations of medicine as they did on Western institutional and scientific models. In his transition from British medical auxiliary to independent entrepreneurial health practitioner, 'Abd al-Ilah deftly navigated the ongoing competition for medical legitimacy between the British, missionaries, Muslim reformers, and local rulers.

Over the course of his work in the dawäkhāna, 'Abd al-Ilah's extensive collection of medical tools marked his status as a skilled professional. 'Abd al-Ilah left artifacts of his surgical and pharmaceutical work, including thread, tweezers, thermometers, scissors, scalpels, vaccination needles, quinine injections, syringes, a stethoscope, and weights and glass containers for measuring and holding medicines. His accounts are precise in terms of how much medicine he sold to a customer, recording the quantity (usually by the jar) and the price per unit in rupees. 'Abd al-Ilah's status as a professional purveyor of curative practices and medical goods seems to have depended on his conversion of the symptoms articulated by his patients into measurable units of temperature, pulse, and price. In the 21 st century, it is the rediscovery of the material remnants of his professionalism that has prompted 'Abd al-Ilah's rehabilitation as a protonational Kuwaiti doctor. These artifacts are displayed in the museum and photographed in the edited volume alongside his documents as evidence of 'Abd al-Ilah's authenticity as a simultaneously modern and native Kuwaiti man of medicine. But his new designation as Kuwait's "first doctor" also has elided other histories, and in telling his story contemporary Kuwaitis actively promote a nativist rendition of the region's pre-oil past. The next section turns to the politics of these recent constructions of health histories that saturate the memory of 'Abd al-Ilah.

\section{The Return of 'Abd Al-Ilah}

In the Gulf, local scholars writing in Arabic have long relied on oral sources to narrate the region's history. ${ }^{63}$ As Fahad Ahmad Bishara has argued, because orality dominated the transmission of knowledge in the pre-oil Gulf, "it is thus natural that oral sources would comprise the foundation of historical writing." ${ }^{64}$ The politics of historiography have changed over time, and so too have the ideological and methodological frameworks of oral histories. Bishara calls on historians to ask "why these histories were produced-whether to legitimate a certain ruler during his reign, to delineate a community in the context of the emergence of the nation-state, or any other reason." ${ }^{65}$ One answer to Bishara's question is that oral narratives-based on individual memories or family lore and recounted to fellow members of the national community-provide an opportunity for citizen families to compete for contemporary importance by emphasizing their ancestors' closeness to ruling elites and their contributions to Kuwait's path toward national modernity.

The location of 'Abd al-Ilah's dawäkhāna directly under the state kishk, the intimacy of his methods of diagnosis and prescription, and the materiality of his remaining artifacts, like his collection of shaykhs' teeth, continue to signal importance as his descendants seek to establish their genealogical embeddedness

\footnotetext{
${ }^{63}$ Talal Al-Rashoud refers to this genre that combines history with firsthand accounts as "hybrid literature" ("Modern Education and Arab Nationalism in Kuwait," 36).

${ }^{64}$ Fahad Ahmad Bishara, "Narrative and the Historian's Craft in the Arabic Historiography of the Gulf," in The Persian Gulf in Modern Times: People, Ports, and History, ed. Lawrence G. Potter (New York: Palgrave Macmillan, 2014), 50.

${ }^{65}$ Ibid., 68.
} 
in the ruling family's inner circle. By recasting 'Abd al-Ilah as the first modern Kuwaiti medical practitioner, these narratives locate the origins of modern Kuwaiti health care-typically described as a hallmark of the post-oil welfare state and dependent on foreign expertise-in a pre-oil and decidedly local lineage. Such accounts draw on multigenerational projects of nation-building that bridge the pre- and post-oil periods and naturalize nativist claims that Arab Muslims are the nation's core constituency.

Historical memory that bends toward the project of building the nation and marking exclusions necessarily casts aside nuance and fabricates teleologies. In contemporary Kuwait, the memory of 'Abd al-Ilah is bifurcated; a dual lens expands the possibilities for his symbolic significance. On the one hand, 21st-century narratives differentiate him from folk medicine because of his British training in colonial medicine. On the other hand, in these accounts 'Abd al-Ilah possesses the exemplary attributes of $a l-t i b b$ al-sha' $b \bar{\imath}$ healers: commitment to community, native roots, and embeddedness in local practices of healing that supersede his imperial ties. This bifurcation allows local scholars and 'Abd al-Ilah's descendants to represent him as simultaneously modern and indigenous. In his symbolic role as Kuwait's first doctor, he both overcomes imperial claims of scientific dominance and proves that Arab Muslims forged their own modernity without forsaking their national and religious heritage.

To understand the significance of casting 'Abd al-Ilah as the first Kuwaiti doctor, it is necessary to pause over the mid-20th-century story that this claim obscures. What historical conditions prompted 'Abd al-Ilah to disappear from narratives of Kuwaiti modernity as a local medical practitioner in the first place? As mentioned above, 'Abd al-Ilah closed his dispensary in the early 1940s, and the timing was not coincidental. Following the discovery of oil in commercial quantities in 1938, the ruling shaykhs' wealth and legitimacy were welded to their ties to the oil company. Sensing that shifting sources of state wealth would result in a loss of political influence, local merchants petitioned the ruler to form an elected council (majlis), which demanded government-funded social services. But when they requested that Shaykh Ahmad (r. 1921-50) grant them oversight of the oil revenues for public expenditure, he dissolved the council. ${ }^{66}$ The ruler claimed direct control over the provisioning of social services, including health care, to the emerging citizen population of Kuwait. Moreover, flanked by expatriate advisors, the shaykh and his nascent welfare state adopted the reliance on foreign expertise and the assumption of Western biomedical superiority that had characterized British imperial and American missionary representations of modernity. 'Abd al-Ilah's family network and medical supply chain had oriented him toward Bombay, but after World War II, nurses and doctors were recruited primarily from Arab countries like Lebanon, Egypt, Palestine, Syria, and Iraq. In this dramatic medical reorientation away from the Indian Ocean and toward the decolonizing Arab world, specialized doctors and centralized hospitals displaced the healthseeking hybridity of 'Abd al-Ilah and his dawākhāna.

The medical and political career of Ahmad al-Khatib exemplifies this mid-20th-century shift in health paradigms as well as the relationship between medicine and politics in Kuwaiti state-building. A renowned opposition leader, al-Khatib had absorbed anti-imperialist and Arab nationalist ideologies in Lebanon and Palestine in the late 1940s and early 1950s while studying medicine. ${ }^{67}$ After his training in surgery at the American University of Beirut, al-Khatib returned to Kuwait in 1952 to work for the Department of Health. ${ }^{68}$ His medical professionalization at an American university (albeit one in Lebanon) places him among a global cohort of medical labor whose "migration in search of higher education helped to resolidify the links between postcolonial knowledge and metropolitan power." al-Khatib whom the Kuwaiti press hailed as Kuwait's first doctor in $1953 .^{70}$ Al-Khatib's foreign training,

\footnotetext{
${ }^{66}$ See Jill Crystal, Oil and Politics in the Gulf: Rulers and Merchants in Kuwait and Qatar (Cambridge, UK: Cambridge University Press, 1990), 47-55.

${ }^{67}$ Abdel Razzaq Takriti, "Political Praxis in the Gulf: Ahmad al-Khatib and the Movement of Arab Nationalists, 1948-1969," in Arabic Thought against the Authoritarian Age: Toward an Intellectual History of the Present, ed. Jens Hanssen and Max Weiss (Cambridge, UK: Cambridge University Press, 2018), 88.

${ }^{68}$ Ahmad al-Khatib, al-Kuwayt: Min al-Imara ila al-Dawla: Dhikrayat al-'Amal al-Watani wa-l-Qawmi (Beirut: al-Markaz al-Thaqafi al-'Arabi, 2007), 100, 103.

${ }^{69}$ Sujani Reddy, Nursing and Empire: Gendered Labor and Migration from India to the United States (Chapel Hill, NC: University of North Carolina Press, 2015), 10.

70"Awwal Tabib Kuwayti," al-Ra'id no. 10 (1953), republished by the Center for Research and Studies on Kuwait, 1999. I am grateful to Alex Boodrookas for sharing this article.
} 
university credentials, and integration into Pan-Arab intellectual networks marked him as the exemplary native doctor during the modernizing frenzy of the early 1950s. ${ }^{71}$ In the decades of aggressive state-driven development that followed World War II, 'Abd al-Ilah was all but cast aside as a relic of an obsolete world.

But in the 21st century, the systematic transference of memories and artifacts from the private family sphere into the public domain has facilitated 'Abd al-Ilah's reemergence as a protonational medical professional. Narrating 'Abd al-Ilah's life and disseminating his story in Kuwait projects a nation-centered concept of public health backward into the past and simply ignores mid-20th-century contestations over the centrality of biomedicine to the politics of state-building. In the figure of 'Abd al-Ilah, structural conditions - the wealth of the oil state as mediated by ruling families and the fact that citizens constituted a minority of the resident population-merged with the dominant oral tradition of Arabic historiography to depict 'Abd al-Ilah as a Kuwaiti medical pioneer who worked to safeguard the health of the national community.

Twenty-first-century representations of 'Abd al-Ilah demonstrate how the act of narrating a biographical historical account creates a discursive field in which participants claim a place in the larger project of national heritage construction. In 2012, a Kuwaiti newspaper published a speech delivered by 'Abd al-Ilah's grandson, Mish'al Talib 'Abd al-Ilah al-Qina'i, at a national conference called "From Kuwait We Begin and in Kuwait We End." "72 The conference's stated purpose was "to honor national Kuwaiti figures" through biographical presentations. ${ }^{73}$ "Abd al-Ilah was "within that constellation" because of his role as "the first Kuwaiti who practiced modern general medicine, dentistry, and pharmacy." The conference, in its ninth consecutive year, took place in al-Babtain Library, a private institution that promotes Arabic poetry and Arab culture and is prominently positioned along Kuwait's corniche. The conference was a multimedia event that relied on narrations of family histories and genealogical claims to present 'Abd al-Ilah as the medical figure among the nation's founding community, a practitioner of modern science who came from the heart of Kuwait's Arab Muslim community. This emphasis obscured the centrality of 'Abd al-Ilah's Bombay and British imperial connections to his medical practice.

The bulk of the newspaper article was devoted to publishing Mish'al's speech "on the impact of this character, his role, and what he offered in terms of treatment services to the people of Kuwait in a time when the country was in need of modern medicine and community development." ${ }^{75}$ Mish al provided a shortened overview of 'Abd al-Ilah's professional biography. Erasing al-'Azmi and skipping over al-Khatib, Mish'al constructed a narrative of health history in which "Kuwaitis did not know modern medicine" until the British opened their dispensary in 1904. For Mishal, moreover, 'Abd al-Ilah had been ideally positioned to translate the skills he learned in the British dispensary because he "spoke the language of [Kuwait's] people and knew their nature and their customs." 76 In this interpretation, only 'Abd al-Ilah could introduce modern medicine to Kuwait precisely because he was positioned between the British and the native Arab community.

The timing of the conference was fortunate. Just a week after the final sessions, 'Abd al-Ilah's last living son, 'Abd al-Rahman, passed away at the age of eighty-six. Attending the conference via video call, he had narrated a story that emphasized "the relationship of friendship that connected his father and Shaykh 'Abd Allah al-Salim," who had overseen Kuwait's formal independence from Britain in 1961 and remains one of the most beloved of Kuwait's rulers (r. 1950-65). ${ }^{77}$ Citing the importance of smallpox vaccination, he recounted how the shaykh had sent one of his personal guards to help 'Abd al-Ilah "in convincing

\footnotetext{
${ }^{71}$ Although al-Khatib features regularly in political histories of Kuwait, none have foregrounded the relationship between his medical training and his political role.

72“'Abd al-Ilah al-Qina'i Awwal Kuwayti Zawal al-Tatbib al-Hadith wa-Iftatah Awwal Saidaliyya bi-Manzilat 'Iyada 'Ilajiyya Khasa," al-Anba', 3 April 2012, https://www.alanba.com.kw/ar/kuwait-news/280567/03-04-2012.

${ }^{73}$ Ibid.

${ }^{74}$ Ibid.

${ }^{75} \mathrm{Ibid}$.

${ }^{76}$ Ibid.

${ }^{77}$ Ibid.
} 
some of the people who were reluctant to vaccinate against the smallpox epidemic." ${ }^{78}$ In presenting this story, 'Abd al-Rahman revealed with pride how his father, 'Abd al-Ilah, had relied on coercive state power in disseminating his medical services. As recounted by his last living son just weeks before his death, this story reminded Kuwaiti conference attendees of the collaborative relationship that had existed between 'Abd al-Ilah and the ruling elites as they joined forces to implement public health efforts that targeted the collective well-being of Kuwait's population even before official political independence. By the timely capture of these memories through video conferencing, the article and the conference made a poignant argument for the urgency of collecting such narratives. Attendees listened to 'Abd al-Ilah's son and grandson narrate his life and achievements. The newspaper then published the speeches, disseminating the family's message to the Kuwaiti public.

In drawing on the biographies of their forebears, certain Kuwaiti families preserve early histories of the seminal nation, but also construct teleologies that accentuate their own importance in the sociopolitical sphere. Contemporary depictions of an ambitious and wily early 20th-century medical practitioner bend seemingly contradictory family memories, material remnants, and British imperial records toward a celebratory narrative of the relationship between medicine and state power that is seminal to Kuwaiti modernity. The process of translating various narrative threads into a biographical story that is legible in a national setting ultimately dilutes 'Abd al-Ilah's medical and social complexity and the transregional connections that made his dawākhāna possible.

Another contemporary discursive thread that enfolds narratives of 'Abd al-Ilah appears in a resurgent interest in preserving, commemorating, and reproducing al-țibb al-shac $b \bar{\imath}$, or folk medicine. As a university-trained doctor who left Kuwait and then returned home carrying foreign medical certification, part of Ahmad al-Khatib's significance was his symbolic severing of folk medicine (constructed as the antithesis to modernization in the early state-building period) from the aggressively modernist health provisions of the developmental state. 'Abd al-Ilah, in contrast, is deployed in 21st-century national narratives to show how folk medicine has lingered on as a deeply rooted marker of cultural authenticity.

The category of $a l-t i b b a l-s h a^{c} b \bar{l}$ as it is used to describe medical practices in this region generally includes performing cautery and cupping, prescribing herbal medicines, setting broken bones, attending to women's and children's health and midwifery, and, finally, conducting religious healing rituals such as reading the Qur'an over a patient. Most translations of $a l-t i b b$ al-sha' $b \bar{\imath}$ miss the contextual nuance of this phrase. Al-tibb, which means medical treatment, medicine, or medical science, can refer to modern biomedicine, but it also has a rich linguistic history in relation to traditional forms of healing, as well as humoral medicine as discussed in classical Arabic-language medical texts. Sha ${ }^{c} b \bar{\imath}$ is the adjective form of $a l$-shac $b$, which can mean people, folk, nation, tribe, or race. In reference to mid-20th-century Arab nationalist parlance, $a l-s^{\prime} b$ has been translated as "the people" of a particular nation or of the transnational Arab world. ${ }^{79}$ Sha ${ }^{c} \bar{\imath}$ also is frequently denoted as "folk," as in folk literature or folk music. In Egypt, for example, since the early 20th century sha'bi has signified the difference between Westernized and privileged elites, and lower-class-but culturally authentic- people $(a l-s h a c b){ }^{80}$ In a political context, it also can refer to the "masses," or even the totality of the nation as represented in the now famous cry of the Arab Spring, "al-sha'b yurìd isqāt al-nizām?" (the people want the overthrow of the regime). In the late 20th- and early 21 st-century Arabian Peninsula, sha' $b \bar{\imath}$ has dramatically different cultural connotations due to demographic conditions in which Arabic-speaking citizens are in the minority and the working classes are often temporary and foreign. ${ }^{81}$ In this context, representations of

\footnotetext{
${ }^{78}$ Ibid.

${ }^{79} \mathrm{Al}$-sha' $b$ might mean, for example, "a social group formed by Iraq's geography, natural traditions, and history”; Orit Bashkin, "Hybrid Nationalisms: Wațan̄ and Qawmī Visions in Iraq under 'Abd al-Karim Qasim, 1958-61," International Journal of Middle East Studies 43, no. 2 (2011): 296.

${ }^{80}$ For analyses of this category in terms of Egyptian music, see, for example, Ted Swedenburg, "Egypt's Music of Protest: From Sayyid Darwish to DJ Haha," Middle East Report 265 (2012): 42; and Daniel J. Gilman, Cairo Pop: Youth Music in Contemporary Egypt (Minneapolis: University of Minnesota Press, 2014), 10.

${ }^{81}$ For a discussion of how Gulf social structures maintain the classification of large populations of foreigners as "outsiders" through an essentialized notion of culture, see Paul Dresch, "Foreign Matter: The Place of Strangers in Gulf Society," in Globalization and the Gulf, ed. John W. Fox, Nada Mourtada-Sabbah, and Mohammed al-Mutawa (London: Routledge, 2006), 200-22.
} 


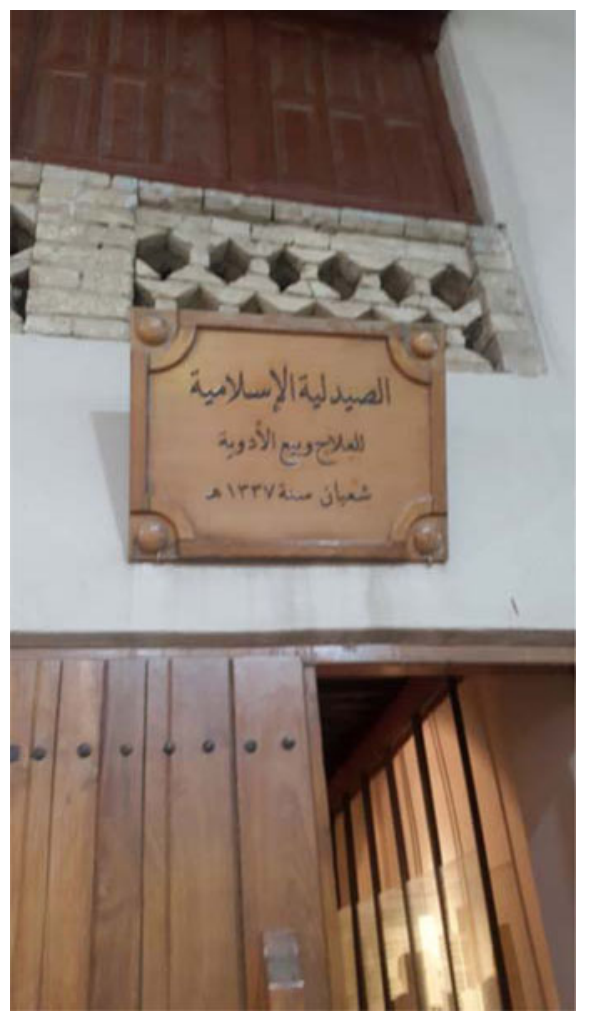

Figure 3. The sign over the entrance to the museum in Suq al-Mubarakiyya. Photograph by the author.

$a l-t i b b a l-s h a^{c} b \bar{\imath}$ emerge out of ongoing politically and ideologically charged efforts to rebrand local culture as national history.

'Abd al-Ilah's grandson, Mish'al al-Qina'i, also described 'Abd al-Ilah as adjacent to, but distinct from, the local al-tibb al-sha'bi healers. He states that "Kuwaitis did not know modern medicine" until the opening of the British dispensary and the American Mission hospital in the early 20th century. Before that, "Kuwaitis relied on Arab or sha'bi medicine, and on their experiences." ${ }^{\prime 2}$ But whereas 'Abd al-Ilah shares folk healers' historical frame of an authentically native pre-oil Kuwait, in his grandson's construction he occupied a distinct medical category, characterized by his intermingling of imperial medicine and locally rooted traditional cures. The British disregarded the contributions of native assistants like 'Abd al-Ilah by omitting their names from official records; ironically, recent Arabic-language accounts of his life return to the British imperial records to demonstrate his role as a medical expert. As 'Abd al-Ilah reemerges as a protonational figure in Kuwaiti memory, the British imperial records are reborn in the postcolonial nation as evidence of a homegrown modernity. In such narratives, the closing of the British dispensary in 1918 catalyzed 'Abd al-Ilah's significance as the native son who would bridge the worlds of $a l-t i b b$ al-sha' $b \bar{\imath}$ and modern medicine. Omitting the decidedly anti-imperialist politics of al-Khatib further reorients Kuwait's medical history away from narratives that might critique the legacy of intimacy between the ruling shaykhs and the British.

In the wider field of imagined Gulf communities, these multiple sources of authenticity converge in the figure of 'Abd al-Ilah and his dawäkhāna. Today, an artistically rustic wooden sign that reads "The Islamic Pharmacy for the Treatment and Sale of Medicines, Sha ban 1337 hijri [May 1919]" is the first encounter visitors have with the museum (Fig. 3). In its designation as an Islamic pharmacy, it is possible that 'Abd al-Ilah's dawäkhāna has been conflated with another pharmacy, established in 1927 by

\footnotetext{
82“"Abd al-Ilah al-Qinaci Awwal Kuwayti Zawal al-Tatbib al-Hadith wa-Iftatah Awwal Saidaliyya bi-Manzilat 'Iyada 'Ilajiyya Khasa," https:/www.alanba.com.kw/ar/kuwait-news/280567/03-04-2012.
} 
'Abd al-Latif al-Duhayyim. ${ }^{83}$ Regardless of the origins of this name, in the context of the 21 st-century Gulf labeling 'Abd al-Ilah's shop as an Islamic pharmacy allows contemporary Kuwaitis to position him as a modern and native historical figure. Assembled under the nebulous label of Islamic medicine, the museum invites visitors to imagine the displacement of Western cultural supremacy by identifying the origins of health and healing in local, Arab, and generically Islamic settings. Portraying 'Abd al-Ilah as Kuwait's first modern medical professional and his shop as an Islamic pharmacy locates the origins of modern medicine in Kuwait in the midst of one of Kuwait's founding families.

\section{Conclusion}

The story of 'Abd al-Ilah's medical practice, his elision in the fury of state-driven modernization, and his eventual resurrection demonstrates how medical praxis saturates political power. The early formulations of this political power, moreover, preceded oil-driven modernity. As the confluence of imperial sanitation, missionary medicine, and the Arab charitable society's activities makes clear, a critical shift in Kuwaiti governance at the start of the 20th century was the emergence of medicine and public health as contested spaces in which local actors reimagined health care and insisted on health services. Although, like Masa'ad bin 'Abd Allah al-'Azmi, 'Abd al-Ilah operated in a medical milieu characterized by transnational and fluctuating cultures and technologies of health, 'Abd al-Ilah's position at the intersection of colonial medicine and local state power differentiated him from his predecessor. By way of nearly a decade of work in the British dispensary, 'Abd al-Ilah was certainly a product of the British Indian medical milieu. Moreover, both in terms of his employment at the British Political Agency and his entrepreneurship underneath the shaykhs' kishk, 'Abd al-Ilah practiced medicine in the shadow of state authority. In turn, this intermediary position between colonial and local medicine and power created the conditions for 'Abd al-Ilah to emerge as a pivotal communicator of the importance of vaccination, a technology of public health that operated beyond individuals seeking health and at the conceptual level of a population of interconnected bodies. By rendering medicine recognizable to multiple audiences, 'Abd al-Ilah was exceptionally well positioned to advance an emerging connection between health and state power in Kuwait.

'Abd al-Ilah passed away in March of 1964, leaving behind a personal archive for his descendants to rediscover decades later. ${ }^{84}$ Although the artifacts of 'Abd al-Ilah's life-his ledgers, the tools from his shop, and the teeth he pulled from the mouths of local notables-have prompted Kuwaitis to reconstruct him as a protonational figure, the concerns of the present animate their interpretations of his remains. 'Abd al-Ilah's recent rediscovery in Kuwait is emblematic of a larger project of national history-making that constructs a nativist vision of the past by obscuring the associations across geographies and populations that made 'Abd al-Ilah's work possible. Yet even as contemporary politics infuse the memory of 'Abd al-Ilah's life and profession, the ledgers and tools that 'Abd al-Ilah left behind also restrain narratives that portray the nation as an enclosed community.

Acknowledgments. I am grateful to Fahad Ahmad Bishara for introducing me to 'Abd al-Ilah. I thank Abdullah Mohammad Alabdullellah Alqenaei for graciously sharing his family history. For their guidance and support, I also would like to thank Osama Abi-Mershed, Mustafa Aksakal, Shaikha Almubaraki, Shaikhah Abdullah Alqenai, Anwar Al-Saad, Carol Benedict, Alex Boodrookas, Alp Eren Topal, Judith Tucker, and Einar Wigen. Joel Gordon and the IJMES anonymous reviewers offered invaluable suggestions. The generous support of a postdoctoral fellowship at the University of Oslo gave me time to revise this article.

\footnotetext{
${ }^{83}$ Citing 'Abd Allah Khalid al-Hatim's Min Huna Bada'at al-Kuwayt, Khalid al-Jarallah discusses al-Dayyim's Islamic pharmacy in his first work on Kuwait's medical history, but does not refer to the Islamic pharmacy in his 2005 introduction to Dawakhana (al-Jarallah, Tarikh al-Khadamat al-Sihhiyya fi al-Kuwayt, 157-58; and al-Jarallah, Dawakhana).

${ }^{84}$ Al-Dayhani, “Abd al-Ilah al-Qinai."
}

Cite this article: Goffman LF (2021). A Jar of Shaykhs' Teeth: Medicine, Politics, and the Fragments of History in Kuwait. International Journal of Middle East Studies 53, 589-603. https://doi.org/10.1017/S0020743821000155 